\title{
Analisis Performansi Protokol Routing Proaktif pada Jaringan Mobile Adhoc
}

\author{
Rohmah Nur Hidayah $^{1 *}$, Indrabayu ${ }^{2}$, Intan Sari Areni ${ }^{1}$ \\ ${ }^{1}$ Departemen Teknik Elektro, Fakultas Teknik, Universitas Hasanuddin, Makassar \\ ${ }^{2}$ Departemen Teknik Informatika, Fakultas Teknik, Universitas Hasanuddin, Makassar \\ J1. Poros Malino km. 6, Bontomarannu, Kabupaten Gowa, Sulawesi Selatan 92171 \\ *Email: rnhidayah.yaya@ gmail.com
}

DOI: 10.25042/jpe.112018.04

\begin{abstract}
Abstrak
Intelligent Transportation Systems (ITS) menawarkan paradigma pemodelan baru yang mendukung komunikasi antar kendaraan secara real time menggunakan routing protocol yang disebut Vehicular Ad Hoc Network (VANET). Pada dasarnya kinerja routing protocol dipengaruhi oleh arus dan aturan lalu lintas yang bersifat dinamis sehingga perubahan tersebut akan menyebabkan perubahan pada kinerja routing protocol juga. Untuk itu, penelitian ini mengusulkan rancangan mobilitas realistis berdasarkan data makroskopis dan mikroskopis jalan perkotaan. Rancangan mobilitas dibagi menjadi 2 skenario berdasarkan kepadatan kendaraan, yaitu 125 dan 200 node. Penelitian ini bersifat simulasi dan dibagi menjadi 2 tahap. Tahap pertama yaitu simulasi mobilitas yang menunjukkan pergerakan kendaraan serta aturan lalu lintas yang disesuaikan dengan kondisi realistis. Tahap kedua adalah simulasi jaringan yang bertujuan untuk mengevaluasi kinerja routing protocol DSDV dan OLSR terhadap rancangan model mobilitas. Untuk menguji kinerja kedua routing protocol, maka digunakan 3 metrik pengujian yaitu Packet Delivery Ratio (PDR), Overhead Ratio (OR) dan End to End Delay (E2ED). Hasil simulasi menunjukkan OLSR unggul pada metrik PDR dan OR, yaitu masing-masing 88.62\% dan 57.11\%. Sedangkan E2ED terbaik ditunjukkan oleh DSDV dengan nilai 0.523 detik. Kinerja terbaik kedua routing protocol ditunjukkan pada skenario 125 node. Hal ini menunjukkan kedua routing protocol belum mampu mengatasi kondisi lalu lintas perkotaan yang sangat padat.
\end{abstract}

\begin{abstract}
Performance Analysis of Proactive Routing Protocols on Adhoc Mobile Networks. Intelligent Transportation Systems (ITS) offers a paradigm with new modeling that supports the communication between vehicles in real time by using a routing protocol called Vehicular Ad Hoc networks (VANET). Basically the routing protocol performance is influenced by the currents and traffic rules which have a dynamic characteristic, so that the changes will cause the changes on the performance of routing protocol as well. Therefore, the study proposes the realistic mobility design based on the macroscopic data and microscopic urban street. The mobility design are divided into 2 scenarios based on the density of vehicles, namely 125 and 200 nodes. It is a stimulation research and divided into 2 stages. The first stage is the simulation of movement which shows the mobility of vehicles and the traffic rules which is tailored with the realistic conditions. The second stage is a simulation network which aims to evaluate the performance of routing protocol of DSDV and OLSR against the design of mobility. To test the performance of both the routing protocol, it is used 3 testing metrics which are Packet Delivery Ratio (PDR), Overhead Ratio (OR) and End to End Delay (E2ED). The results of the simulation shows OLSR is superior on PDR and OR metric, each $88.62 \% 57.11 \%$. While the best E2ED is showed by DSDV with score 0.523 seconds. The second-best performance of routing protocol is showed in scenario 125 nodes. It shows that both of the routing protocol has not been able yet to overcome the heavy conditin of urban traffic.
\end{abstract}

Kata Kunci: DSDV, E2ED, realistic mobility, routing protocol, VANET

\section{Pendahuluan}

Mobilitas masyarakat sangat dipengaruhi oleh perkembangan sistem transportasi. Setiap tahun, volume dan kepadatan kendaraan meningkat secara signifikan yang mengarah pada peningkatan kecelakaan dan kemacetan [1]. Di
Indonesia sendiri, berdasarkan data Badan Pusat Statistik, jumlah kendaraan juga mengalami peningkatan terutama di kota-kota besar yang mencapai $8-12 \%$ setiap tahunnya. Selain itu, dampak lain yang ditimbulkan adalah waktu tempuh kendaraan yang tidak pasti dan penurunan 
produktivitas masyarakat. Meskipun peraturan lalu lintas telah dibuat untuk mengontrol traffic dan kontruksi perluasan jalan telah dilakukan namun solusi ini tidak menyelesaikan masalah lalu lintas yang semakin kompleks terutama permintaan transportasi yang tidak terkontrol [2].

Untuk mengatasi masalah tersebut, maka Intelligent Transportation Systems (ITS) menawarkan paradigma pemodelan baru yang mengintegrasikan teknologi jaringan, wireless dan jaringan lalu lintas yang mendukung komunikasi antar kendaraan di jalan secara real time [3]. Teknologi ini disebut Vehicular Ad Hoc Network (VANET). Teknologi ini merupakan salah satu pendekatan yang mampu memastikan produktivitas dan mobilitas yang lebih aman dan efisien dengan memanfaatkan infrastuktur dan layanan yang ada [4].

Dalam melakukan komunikasi, node (kendaraan) menggunakan routing protocol untuk mentransmisikan paket data. Proses transmisi data pada VANET berbeda dengan jaringan pada umumnya yang bersifat statis. Perutean paket mengikuti gerakan node dan mengakibatkan topologi jaringan VANET bersifat dinamis. Karakteristik ini menjadi tantangan untuk routing protocol dalam menciptakan komunikasi data yang efektif dan efisien [5].

Hal lain yang mempengaruhi kinerja routing protocol adalah kepadatan, distribusi kendaraan dan kecepatan kendaraan [6]. Pada wilayah perkotaan, pergerakan kendaraan tidak stabil dan sulit diprediksi karena adanya percepatan dan perlambatan kendaraan, distribusi kendaraan yang tidak merata menyebabkan jalan tertentu mengalami kemacetan sedangkan jalan lainnya lengang. Selain itu, pembatasan geografis dan aturan lalu lintas juga mempengaruhi kinerja routing protocol dalam mentransmisikan data.

Berbagai faktor yang mempengaruhi kinerja routing protocol pada dasarnya merupakan parameter arus dan aturan pada lalu lintas. Sehingga, dapat dikatakan bahwa perubahan topologi jalan akan menyebabkan perubahan pada kinerja routing protocol juga [7]. Karena node dicirikan menyebabkan mobilitas yang tinggi, maka pola mobilitas dapat secara signifikan mempengaruhi hasil simulasi [8].
Untuk itu, perancangan dan pembangunan model mobilitas realistis perlu dilakukan sebelum melakukan pengujian terhadap routing protocol [5]. Mengingat setiap skenario jalan memiliki fitur, kriteria dan persyaratannya masing-masing, maka perancangan ini bersifat simulasi karena selain ekonomis, pengujian routing protocol dapat dilakukan secara berulang sebelum di aplikasikan pada dunia nyata $[9,10]$. Di samping itu, penataan lalu lintas yang lebih efektif dapat dilakukan melalui evaluasi kinerja routing protocol jika diperlukan.

Sejumlah penelitian telah dilakukan untuk membangun dan menerapkan rancangan mobilitas realistis pada VANET serta menguji kinerja routing protocol pada model mobilitas tersebut. Akhtar et al membangun skenario model mobilitas realistis jalan tol dengan mengintegrasikan topologi jalan di dunia nyata dengan data real-time kendaraan dari database Performance Measurement System (PeMS) menggunakan SUMO untuk menghasilkan arus lalu lintas yang realistis di jalan tol. Dengan berfokus pada model channel hambatan, penelitian ini menunjukkan kecocokan Obs model dengan kepadatan kendaraan [11]. Sementara, Lee dkk. membangun model mobilitas realistis menggunakan data jaringan jalan dan sinyal lalu lintas pada kota Kinabalu. Hasil penelitian menunjukkan kepadatan tinggi dari node bisa meningkatkan konektivitas jaringan dan pengiriman tetapi juga bisa mewujudkan tabrakan paket yang tinggi. Di samping itu, konektivitas node dengan dan tanpa sinyal lalu lintas memiliki perbedaan yang siginifikan [12].

Berbeda dengan penelitian sebelumnya, Basta et al mengintegrasikan aspek mobilitas sosial dan pembatasan mobilitas geografis ke dalam kerangka matematis untuk memprediksi mobilitas kendaraan. Evaluasi model mobilitas menunjukkan kecocokan rata-rata $85 \%$ dengan data real [13]. Penelitian lain dilakukan oleh Nwizege et al yang membangun mobilitas menggunakan model matematika dan hasil penelitian menunjukkan adanya peningkatan sinyal dan mempertahankan komunikasi antar kendaraan. Hasil simulasi juga membantu untuk memperkirakan jarak transmisi yang sesuai [14]. 
Berdasarkan penelitian-penelitian tersebut, maka penelitian ini berfokus untuk membangun mobilitas realistis berdasarkan data makrosopis dan mikroskopis dari jaringan lalu lintas. Kemudian menganalisis kinerja routing protocol yang sesuai dengan skenario perkotaan terhadap usulan model mobilitas dan membandingkannya dengan model mobilitas acak.

\section{Skenario Mobilitas Perkotaan}

Penelitian ini menggunakan Jl. AP. Pettarani, Kota Makassar sebagai lingkungan simulasi. Daerah ini dipilih dengan pertimbangan indeks tingkat pelayanan jalan yang mendekati kapasitas jalan dengan karakteristik kondisi operasional dalam arus lalu lintas yang tidak stabil. Adapun tahap simulasi diawali dengan merancang mobilitas yang realistis, kemudian dilanjutkan dengan simulasi mobilitas dan tahap akhir adalah simulasi jaringan.

\subsection{Perancangan Mobilitas Realistis}

Untuk merancang skenario mobilitas dibutuhkan data makroskopis berupa kepadatan dan distribusi kendaraan. Dan data mikroskopis berupa tuntutan lalu lintas, seperti aturan lalu lintas, arah gerak kendaraan termasuk posisi sumber dan tujuan kendaraan, jumlah traffic light, durasi traffic light, serta kecepatan kendaraan [15].

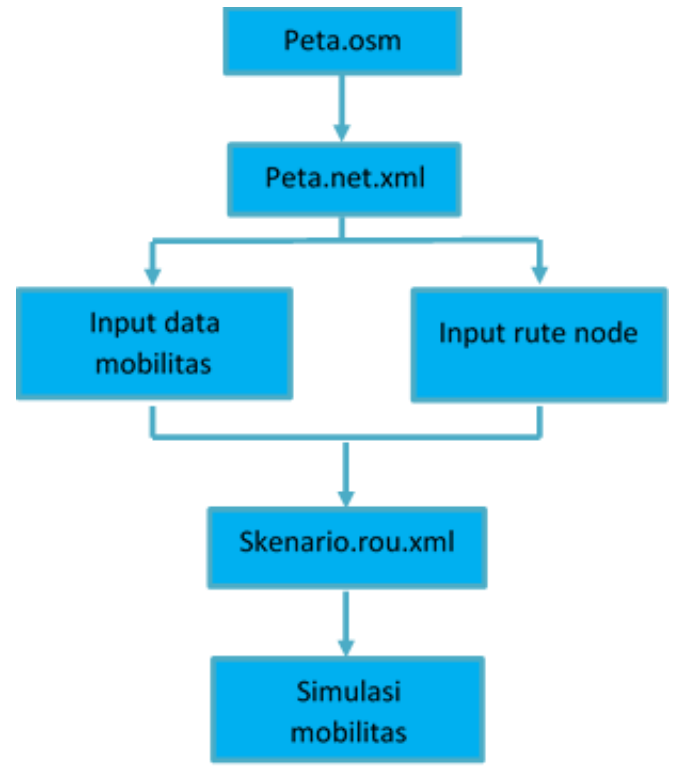

Gambar 1. Alur pembuatan mobilitas realistis
Data-data tersebut akan diinput ke dalam Simulation Urban Mobility (SUMO). Selain untuk simulasi lalu lintas, SUMO juga mampu membangun jaringan jalan yang luas menggunakan data mikrokskopis dan makroskopis [16]. Adapun alur pembuatan skenario realistis dapat dilihat pada Gambar 1.

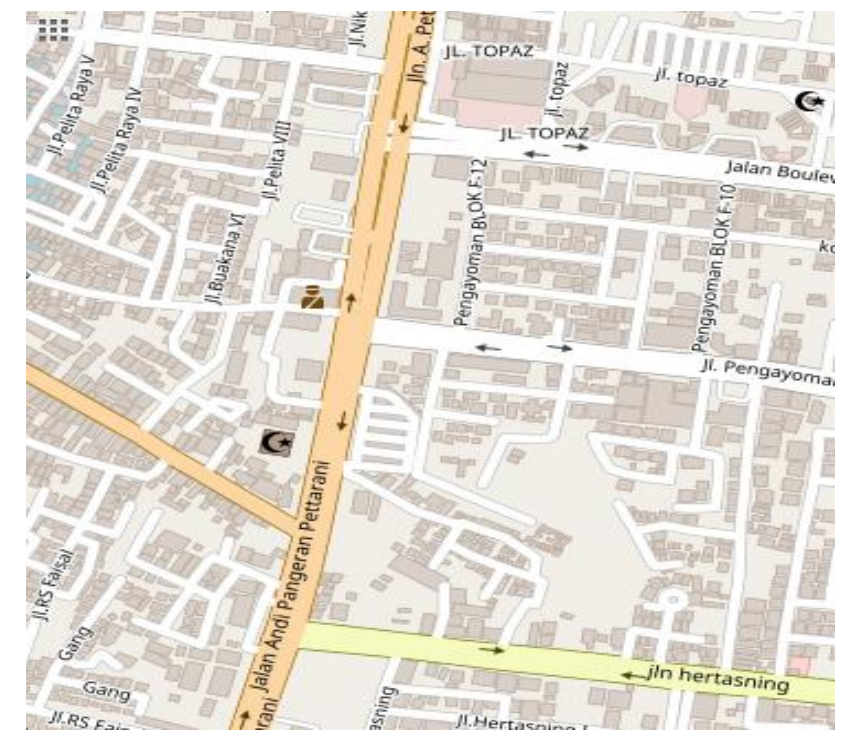

Gambar 2. Peta Jalan AP. Pettarani, Kota Makassar

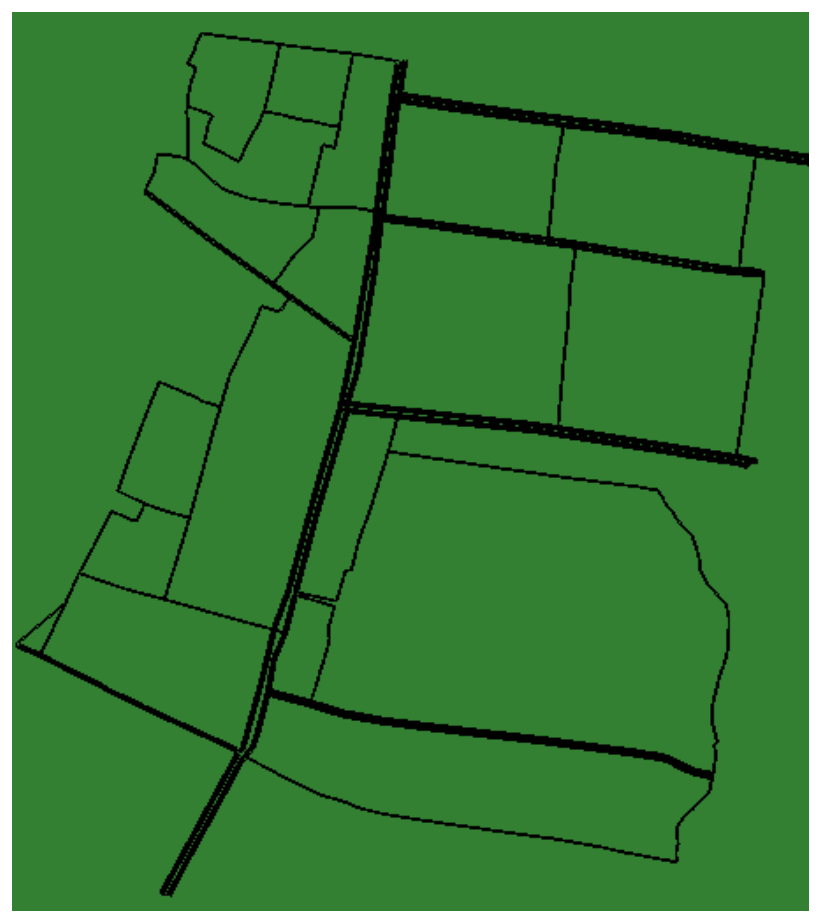

Gambar 3. Proses edit peta simulasi 
Untuk membangun mobilitas realistis, digunakan peta jalan yang bersumber dari OpenStreetMap (OSM) seperti yang ditunjukkan pada Gambar 2. OSM digunakan karena memiliki informasi geografis yang update dan peta dapat di konversi sehingga dapat digunakan di SUMO [17]. Peta yang bersumber dari OSM terlebih dahulu dikonversi menjadi file dengan format .net.xml dengan fungsi NETCONVERT.

Konversi ini bertujuan agar peta dapat digunakan oleh tool SUMO seperti yang ditunjukkan pada Gambar 3. Setelah itu, dilakukan penginputan parameter mobilitas dari data mikroskopis dan makroskopis sesuai dengan kondisi nyata jalan AP. Pettarani Adapun parameter yang menjadi inputan adalah panjang jalan, jumlah jalur, kecepatan kendaraan, jumlah lampu lalu lintas, interval lampu lalu lintas, aturan lalu lintas, dan konektivitas setiap jalan. Parameter ini diinput dan diubah menggunakan fungsi NETEDIT sehingga menghasilkan peta seperti yang ditunjukkan pada Gambar 4.

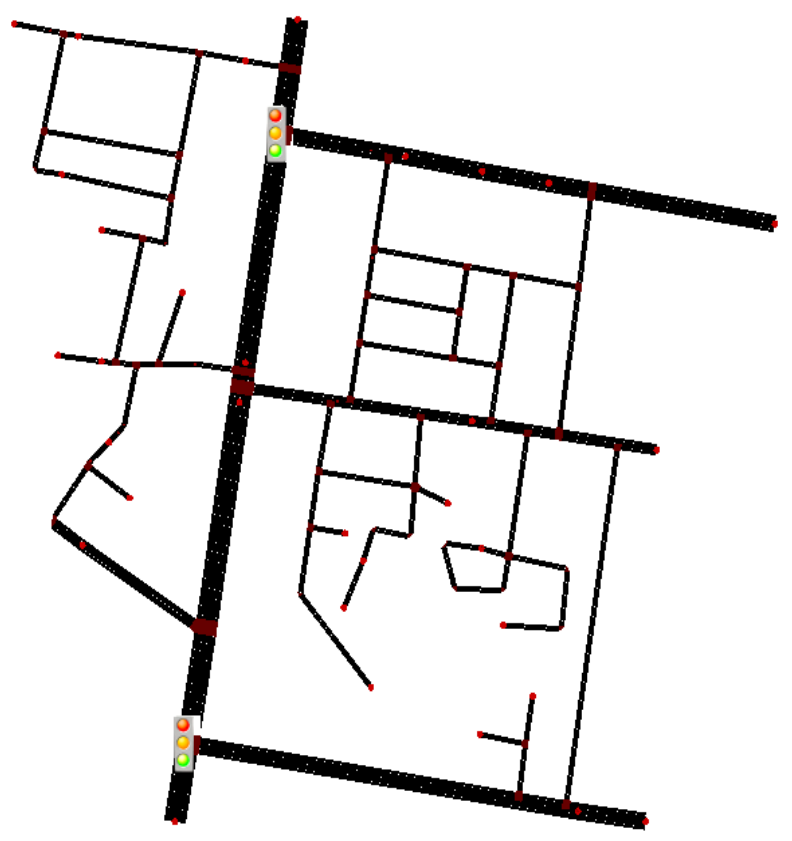

Gambar 4. Peta simulasi

Langkah selanjutnya adalah mengatur jumlah kendaraan, arah keberangkatan dan tujuan kendaraan sehingga rute kendaraan sesuai dengan kondisi jalan. Rute ini ditentukan berdasarkan hasil observasi langsung, sedangkan untuk jumlah node ditentukan berdasarkan data Laboratoium
Transportasi, Teknik Sipil, Universitas Hasanuddin tahun 2016. Untuk menyesuaikan jumlah kendaraan dengan waktu simulasi (60 detik), maka digunakan rumus berikut:

$$
K=\frac{(N \times T)}{60}
$$

di mana $N$ adalah jumlah node per jam dan $T$ adalah waktu simulasi.

Berdasarkan hasil observasi dan perhitungan di atas, diperoleh rata-rata jumlah node sebanyak 125-200 per menit. Setelah itu, peta simulasi dikonversi menjadi file .rou.xml berdasarkan jumlah dan gerakan node tersebut. Pada penelitian ini, digunakan 2 skenario berdasarkan jumlah node, yaitu 125 dan 200 . Skenario ini dipilih karena mewakili kondisi lalu lintas saat padat dan saat lengang. Hal ini dilakukan untuk menguji kinerja routing protocol saat kondisi padat mapun sebaliknya.

\subsection{Simulasi Mobilitas}

Simulasi mobilitas dilakukan untuk menguji rancangan mobilitas yang telah dibuat sebelum diimplementasikan pada simulasi jaringan. Simulasi mobilitas menunjukkan pergerakan kendaraan serta aturan lalu lintas yang telah dibuat sebelumnya. Hal ini dilakukan untuk mengantisipasi jika terjadi kesalahan pada peta dan lingkungan simulasi.

Sebelum menjalankan simulasi terlebih dahulu dilakukan konfigurasi terhadap peta simulasi untuk menghasilkan Graphical User Interface (GUI) SUMO dengan format sumo.cfg seperti yang ditunjukkan pada Gambar 5. Konfigurasi ini menggunakan file .net.xml sebagai inputan peta dan menggunakan file rou.xml sebagai inputan gerakan node. Gambar 6 menunjukkan rute gerakan kendaraan pada file rou.xml. Dengan format sumo.cfg, SUMO mampu menginterpretasikan mobilitas kendaraan dalam dunia nyata. Seluruh parameter yang telah diinput dalam file net.xml dan rou.xml terlihat selama simulasi. Selain itu, simulasi juga menunjukkan warna node yang berbeda-beda. Hal ini untuk melihat adanya percepatan dan perlambatan dari setiap node. Saat mobil melakukan perlambatan dan percepatan, warna mobil berubah menjadi 
orange jika perubahan yang terjadi antara $0-8 \mathrm{~m} / \mathrm{s}$, sedangkan akan berubah menjadi kuning muda jika percepatan atau perlambatan terjadi antara 8$16 \mathrm{~m} / \mathrm{s}$ seperti yang ditunjukkan pada Tabel 1 .

Tabel 1. Kecepatan node

\begin{tabular}{cc}
\hline Warna Node & Kecepatan Kendaraan \\
\hline Merah & $0 \mathrm{~m} / \mathrm{s}$ \\
Kuning & $1-8 \mathrm{~m} / \mathrm{s}$ \\
Hijau & $9-15 \mathrm{~m} / \mathrm{s}$ \\
\hline
\end{tabular}

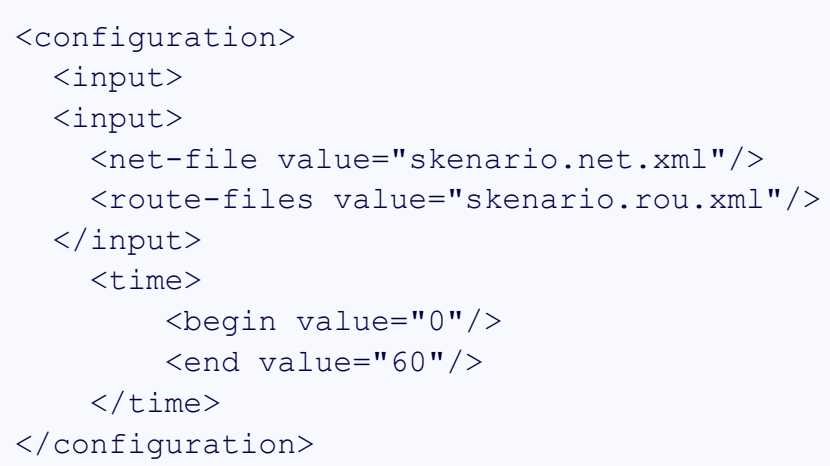

Gambar 5. Konfigurasi SUMO

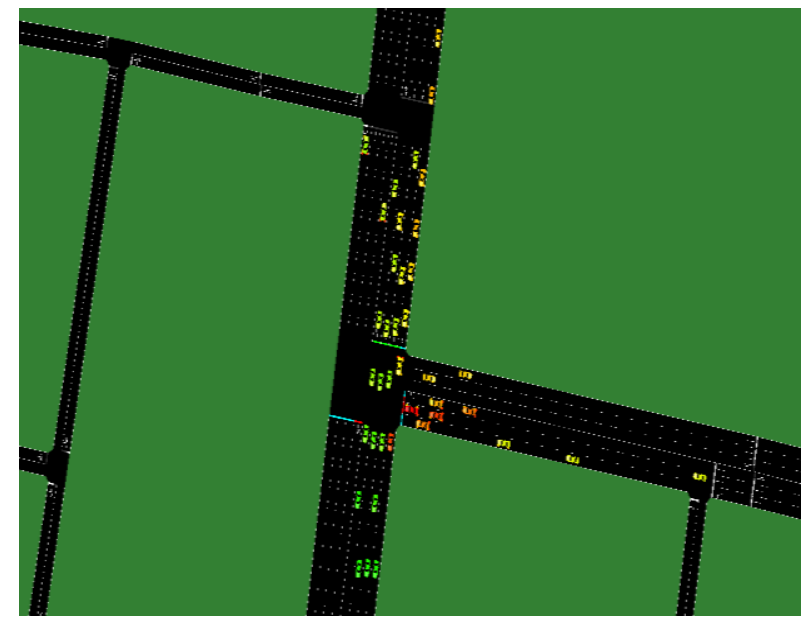

Gambar 6. Simulasi Mobilitas

\section{Simulasi Jaringan}

Dalam melakukan simulasi jaringan, VANET menggunakan Medium Access Control (MAC) protocol untuk melakukan komunikasi data antar node. Penelitian ini menggunakan rancangan MAC IEEE 802.11p yang mewarisi aturan utama standar MAC 802.11 untuk Wireless Access in Vehicular Environment (WAVE) yang mendukung Intelligent Transportation System
(ITS). Hal ini membuat IEEE 802.11p dapat melakukan pertukaran data berkecapatan tinggi antara node sehingga sesuai untuk lingkungan VANET dengan karakterisik topologi yang dinamis [18].

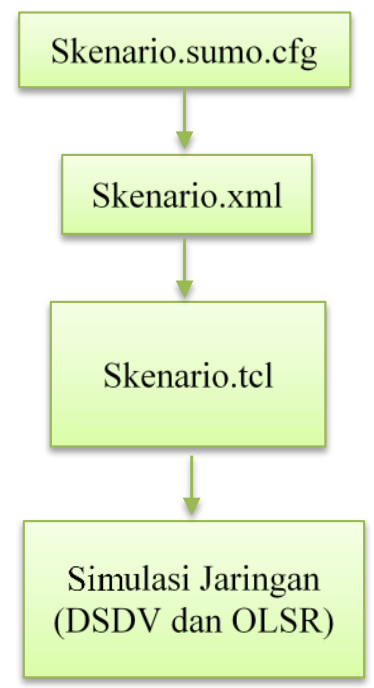

Gambar 7. Alur simulasi jaringan

Tabel 2. Parameter simulasi jaringan

\begin{tabular}{ll}
\multicolumn{1}{c}{$\begin{array}{c}\text { Parameter Simulasi } \\
\text { Jaringan }\end{array}$} & \multicolumn{1}{c}{ Nilai } \\
\hline Simulator mobilitas & $\begin{array}{l}\text { Urban Scenario, Created on } \\
\text { Sumo-0.25.0 }\end{array}$ \\
Simulator jaringan & NS-3.24 \\
Routing Protocol & DSDV and OLSR \\
Waktu simulasi & $60 \mathrm{~s}$ \\
Jarak transmisi & $150 \mathrm{~m}$ \\
MAC Layer & IEEE 802.11p \\
Ukuran paket data & 200 Byte \\
Jenis Pesan & Basic Safety Message (BSM) \\
Jumlah paket data & 10 packet/s \\
Loss Model & Nakagami model \\
\hline
\end{tabular}

Adapun parameter simulasi jaringan ditunjukkan pada Tabel 2 dan alur simulasi jaringan ditunjukkan pada Gambar 7. Untuk melakukan simulasi jaringan, terlebih dahulu file .sumo.cfg dikonversi ke dalam bentul file .xml. Selanjutnya jejak mobilitas berupa floating car data (fcd) yang berisi lokasi dan kecepatan dari setiap node pada setiap waktu di konversi melalui traceExporter.py. Hasil dari konversi ini adalah trace file yang berisi aktifitas dan informasi lifetime dari setiap node dengan format .tcl yang dapat diolah oleh NS3. 
Setelah parameter simulasi ditentukan, selanjutnya dilakukan simulasi jaringan. Simulasi ini bertujuan untuk mengevaluasi kinerja routing protocol terhadap rancangan model mobilitas.

Adapun routing protocol yang digunakan adalah Destination Sequenced Distance Vector (DSDV) dan Optimized Link State Routing (OLSR). DSDV merupakan modifikasi dari algoritma Bellman-Ford dengan atribut baru berupa sequence number yang menyimpan semua informasi ke dalam tabel routing pada setiap node [19, 20]. Keunggulan dari DSDV adalah menyederhanakan rute pengiriman paket dan menghindari terjadinya looping jaringan [21].

Sedangkan OLSR digunakan karena sesuai untuk jaringan dengan mobilitas node yang tinggi [22]. Keunggulan OLSR adalah mengurangi jumlah pesan broadcast dengan informasi yang sama serta mengurangi jumlah overhead. Hal ini karena adanya node Multipoint Relays (MPR) yang berfungsi untuk meneruskan paket, sehingga paket tidak bertumpuk di jaringan [23].

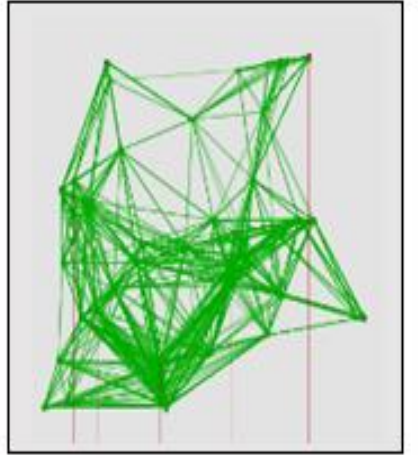

(a) Simulasi Jaringan dengan DSDV

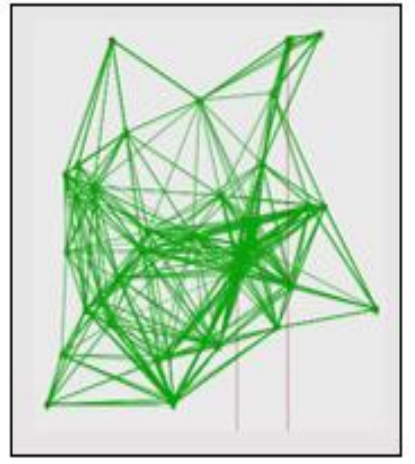

(b) Simulasi Jaringan dengan OLSR
Gambar 8. Hasil Simulasi Jaringan

Untuk menguji kinerja dari DSDV dan OLSR maka digunakan 3 metrik pengujian yaitu Packet Delivery Ratio (PDR), Overhead Ratio (OR) dan End to End Delay (E2ED) [24, 25].

a) Packet Delivery Ratio (PDR) merupakan rasio perbandingan antara jumlah paket yang berhasil diterima $\left(P_{r}\right)$ oleh node tujuan dengan jumlah paket yang dikirimkan $\left(P_{s}\right)$ ke node tujuan. Perbandingan paket yang dihitung hanya Basic Safety Messange (BSM) yaitu, paket yang dikirim dari node sumber ke node tujuan.

$$
P D R=\frac{\sum P r}{\sum P s}
$$

b) Overhead Ratio (OR) adalah rasio perbandingan antara ukuran control packet $(C P)$ terhadap ukuran total packet data $(P D)$ yang berhasil dikirim ke node tujuan.

$$
O R=\frac{C P}{\sum P D}
$$

c) End to End Delay (E2ED) merupakan akumulasi delay rata-rata paket yang berhasil diterima selama proses pengiriman paket berdasarkan waktu simulasi.

$$
E 2 E D=\sum_{i-0}^{n}\left(\mathrm{Pr}_{\mathrm{i}}-\mathrm{Pt}_{\mathrm{i}}\right)
$$

dimana $\operatorname{Pr}$ adalah waktu saat paket diterima, $P t$ adalah waktu saat paket ditransmisikan.

\section{Analisis dan Evaluasi Hasil Simulasi}

Hasil simulasi jaringan terhadap routing protocol DSDV dan OLSR ditunjukkan pada Gambar 8. Berbeda dengan simulasi mobilitas, pada simulasi jaringan, yang tampak hanya koneksi antar node saja. Warna hijau menunjukkan proses transmisi paket dan ketika terjadi packet loss akan ditandai dengan garis berwarna merah. OLSR memiliki packet loss yang lebih sedikit dibanding DSDV. Hal ini dikarenakan paket yang ditansmisikan dari node sumber ke node tujuan diteruskan oleh MPR, sehingga kepadatan jaringan dapat diminimalisir. Teknik ini secara signifikan akan mengurangi jumlah transmisi ulang yang akan membanjiri jaringan dengan prosedur broadcast. Saat suatu node dipilih sebagai MPR, maka node lain yang sejajar tidak akan melakukan transmisi paket melainkan hanya bertugas untuk mengupdate kondisi routing.

Walaupun kedua routing protocol yang digunakan merupakan routing protocol proaktif. Akan tetapi, evaluasi dari metrik analisis menunjukkan hasil yang berbeda. Hasil analisis dan evaluasi kinerja routing protocol DSDV dan OLSR diuraikan sebagai berikut. 


\section{- Packet Delivery Ratio (PDR)}

Gambar 9 menunjukkan perbandingan PDR antara DSDV dan OLSR. Pada grafik dapat dilihat kinerja OLSR lebih baik dibandingkan DSDV. PDR tertinggi adalah $88.62 \%$ pada skenario dengan jumlah nodel 125 yang ditunjukkan oleh OLSR dan PDR terendah ditunjukkan oleh DSDV pada skenario 200 node dengan nilai $80.05 \%$. Hal ini disebabkan oleh jumlah node jumlah node yang berbanding lurus dengan jumlah transmisi paket, sehingga skenario dengan jumlah node paling sedikit memperoleh PDR terbaik.

OLSR memiliki performansi yang lebih baik karena OLSR mewarisi sifat kestabilan dari algoritma link state dan segera menyediakan rute ketika dibutuhkan. Dengan adanya multihop pada OLSR, paket tetap dapat diterima oleh node tujuan walaupun kondisi node selalu bergerak. Selain itu, masing-masing node mengirimkan control packet secara berkala sehingga dapat meminimalisir terjadinya packet loss saat terjadi gangguan transmisi.

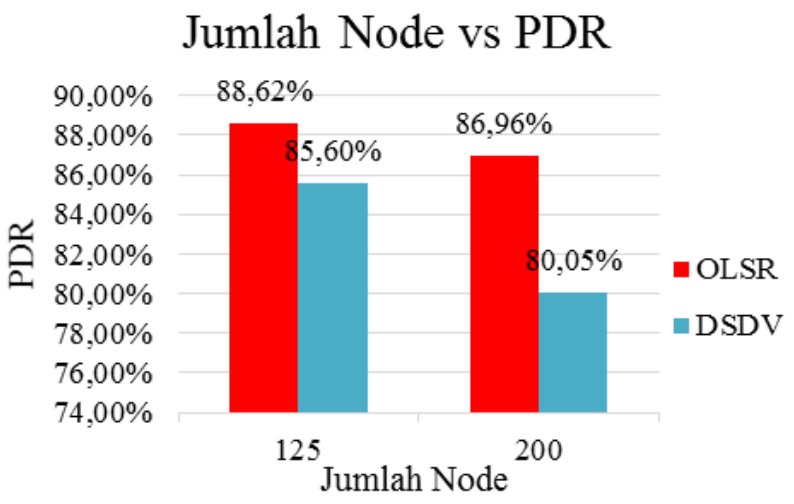

Gambar 9. Pengaruh jumlah node terhadap PDR

\section{- Overhead Ratio (OR)}

Grafik Overhead Ratio pada kedua routing protocol ditunjukkan pada Gambar 10. Hasil simulasi memperlihatkan overhead pada OLSR menunjukkan performasi yang lebih rendah dibandingkan DSDV. OLSR memiliki nilai overhead sebesar $57.11 \%$ pada skenario 125 node. Sedangkan overhead tertinggi sebesar $89.56 \%$ diperoleh DSDV pada skenari 200 node.

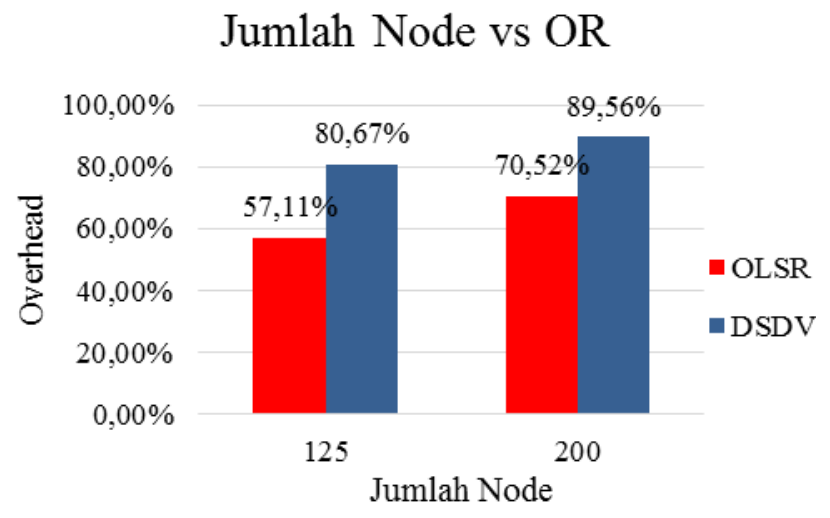

Gambar 10. Pengaruh jumlah node terhadap OR

Berbeda dengan PDR, Overhead justru menunjukan perbedaan yang signifikan terhadap kinerja kedua routing protocol. Hal ini karena adanya Multipoint Relay (MPR) pada OLSR yang bertujuan untuk meminimalisir overhead dari pesan broadcast pada jaringan dengan cara mengurangi transmisi ulang. Selain itu, sebelum melakukan transmisi, terlebih dahulu OLSR akan mengurangi ukuran packet control yang dibroadcast ke setiap node. Hal ini otomatis mengurangi penggunaan bandwidth, sehingga overhead jaringan ikut berkurang.

- End to End Delay (E2ED)

Pada E2ED, performansi kedua routing protocol menunjukkan hasil yang hamper sama dengan rata-rata delay 0.5 detik. Berbeda dengan PDR dan OR, DSDV justru menunjukkan performansi yang lebih baik dibandingkan OLSR pada E2ED seperti yang ditunjukkan pada Gambar 11. Delay terendah 0.523 detik yang diperoleh oleh DSDV pada skenario 125 node. Sedangkan delay tertinggi ditunjukkan oleh OLSR pada skenario 200 node dengan nilai 0.555 detik.

DSDV memiliki delay terendah karena adanya sequence number pada setiap node yang diupdate secara berkala. Tabel routing dipertahankan secara periodic dan ketika terjadi perubahan maka sequence number akan merubah urutan node untuk transmisi paket. Disamping itu, DSDV mengadopsi algoritma djistra dari Bellman-Ford sehingga, saat akan melakukan transmisi, node sumber akan mencari jarak terdekat untuk sampai ke node tujuan. 


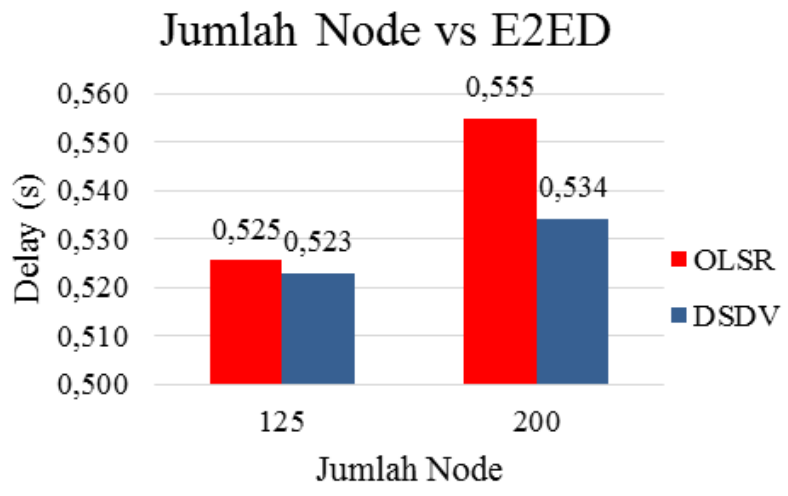

Gambar 11. Pengaruh jumlah node terhadap E2ED

Walaupun keduanya merupakan routing protocol proaktif yang mampu mengurangi transmisi ulang yang menjadi penyebab delay, tetapi DSDV tidak memerlukan waktu yang lama saat melakukan transmisi karena adanya sequence number pada node. Berbeda dengan OLSR yang membutuhkan waktu untuk mimilih MRP dan mengurangi ukuran paket kontrol. Hal ini membutuhkan waktu dan menyebabkan delay pada proses transmisi paket.

\section{Kesimpulan}

Penelitian ini mengusulkan model mobilitas realistis untuk menguji performansi routing protocol DSDV dan OLSR terhadap kondisi lalu lintas perkotaan menggunakan 3 metrik analisis, yaitu PDR, OR dan E2ED. Berdasarkan hasil simulasi, diperoleh hasil yang berbeda pada kedua jenis routing protocol proaktif ini. Hasil simulasi menunjukkan PDR tertinggi sebesar $88.62 \%$ pada seknario 125 node menggunakan OLSR. Dan pada OR kinerja terbaik juga ditunjukkan oleh OLSR dengan persentase overhead terendah $57.11 \%$. Sedangkan pada E2ED, walaupun ratarate delay hamper sama, hasil terbaik diperoleh DSDV dengan nilai 0.523 detik pada skenario 125 node.

Kinerja kedua routing protocol mengalami fase terbaik pada scenario 125 node. Hal ini menunjukkan kedua routing protocol belum mampu mengatasi kondisi lalu lintas perkotaan yang sangat padat.

\section{Referensi}

[1] C. J. Khisty, Transportation engineering: an introduction, 3rd ed. Upper Saddle River, N.J.: Prentice Hall, c2003.

[2] M. Alam, J. Ferreira, and J. Fonseca, "Introduction to Intelligent Transportation Systems," in Intelligent Transportation Systems, Springer, Cham, 2016, pp. 117.

[3] W. Liang, Z. Li, H. Zhang, S. Wang, and R. Bie, "Vehicular Ad Hoc Networks: Architectures, Research Issues, Methodologies, Challenges, and Trends," Int. J. Distrib. Sens. Netw., vol. 11, no. 8, p. 745303, Aug. 2015.

[4] M. Janić (auth.), Advanced Transport Systems: Analysis, Modeling, and Evaluation of Performances, 1st ed. Springer-Verlag London, 2014.

[5] M. Abdelgadir, R. A. Saeed, and A. Babiker, "Mobility Routing Model for Vehicular Ad-hoc Networks (VANETs), Smart City Scenarios," Veh. Commun., vol. 9, pp. 154-161, Jul. 2017.

[6] R. M. Tufail, "Review of Routing Protocols in VANETs," 2016.

[7] P. S. N. Darisini and N. S. Kumari, "A survey of routing protocols for VANET in urban scenarios," in 2013 International Conference on Pattern Recognition, Informatics and Mobile Engineering, 2013, pp. 464467.

[8] F. Benabdallah, A. Hamza, and M. Bechrif, "Simulation and analysis of VANETS performances based on the choice of mobility model," in 2017 Computing Conference, 2017, pp. 1238-1242.

[9] B. Boukenadil, "Importance of realistic mobility models for vanet network simulation," Int. J. Comput. Netw. Commun., vol. 6, no. 5, pp. 175-182, Sep. 2014.

[10] S. Al-Sultan, M. M. Al-Doori, A. H. Al-Bayatti, and H. Zedan, "A comprehensive survey on vehicular Ad Hoc network," J. Netw. Comput. Appl., vol. 37, pp. 380392, Jan. 2014.

[11]N. Akhtar, S. C. Ergen, and O. Ozkasap, "Vehicle Mobility and Communication Channel Models for Realistic and Efficient Highway VANET Simulation," IEEE Trans. Veh. Technol., vol. 64, no. 1, pp. 248-262, Jan. 2015.

[12] C. H. Lee, K. G. Lim, B. L. Chua, R. K. Y. Chin, and K. T. K. Teo, "Progressing toward urban topology and mobility trace for Vehicular Ad Hoc Network (VANET)," in 2016 IEEE Conference on Open Systems (ICOS), 2016, pp. 120-125.

[13] N. Basta, A. ElNahas, H. P. Grossmann, and S. Abdennadher, "Generic Geo-Social Mobility Model for VANET," in 2016 IEEE 84th Vehicular Technology Conference (VTC-Fall), 2016, pp. 1-5.

[14]P.-K. Friday Oodee and G. Ikhazuangbe, "Using Derived Mobility Model Metrics to Evaluate the Impact of Transmission Range in Vehicular Networks," vol. 7, Mar. 2018. 
[15]R. Guyonnet, J. Monteil, B. Ghosh, and M. Bouroche, "Empirical and Simulation Analysis of the Relation between Microscopic and Macroscopic Traffic Considering Trajectory Data Sets," presented at the Transportation Research Board 96th Annual MeetingTransportation Research Board, 2017.

[16] D. Krajzewicz, J. Erdmann, M. Behrisch, and L. Bieker, "Recent Development and Applications of SUMO Simulation of Urban MObility," Int. J. Adv. Syst. Meas., vol. 5, pp. 128-138, Dec. 2012.

[17]F. Ramm, J. Topf, and S. Chilton, OpenStreetMap: Using and Enhancing the Free Map of the World. UIT Cambridge, 2010.

[18] A. Laouiti, A. Qayyum, and M. N. M. Saad, Eds., Vehicular Ad-Hoc Networks for Smart Cities: Second International Workshop, 2016. Springer Singapore, 2017.

[19]T. E. Ali, L. A. K. al Dulaimi, and Y. E. Majeed, "Review and performance comparison of VANET protocols: AODV, DSR, OLSR, DYMO, DSDV ZRP," in 2016 Al-Sadeq International Conference on Multidisciplinary in IT and Communication Science and Applications (AIC-MITCSA), 2016, pp. 1-6.

[20] P. Mutalik, N. S, V. J, R. V. Biradar, and V. G. C. Patil, "A comparative study on AODV, DSR and DSDV routing protocols for Intelligent Transportation System (ITS) in metro cities for road traffic safety using
VANET route traffic analysis (VRTA)," in 2016 IEEE International Conference on Advances in Electronics, Communication and Computer Technology (ICAECCT), 2016, pp. 383-386.

[21]B. Hamid and E. N. E. Mokhtar, "Performance analysis of the Vehicular Ad hoc Networks (VANET) routing protocols AODV, DSDV and OLSR," in 2015 5th International Conference on Information Communication Technology and Accessibility (ICTA), 2015, pp. 1-6.

[22] T. S. Chouhan and R. S. Deshmukh, "Analysis of DSDV, OLSR and AODV Routing Protocols in VANETS Scenario: Using NS3," in 2015 International Conference on Computational Intelligence and Communication Networks (CICN), 2015, pp. 85-89.

[23] A. Dua, N. Kumar, and S. Bawa, "A systematic review on routing protocols for Vehicular Ad Hoc Networks," Veh. Commun., vol. 1, no. 1, pp. 33-52, Jan. 2014.

[24] X. Zhang, X. Cao, L. Yan, and D. K. Sung, "A StreetCentric Opportunistic Routing Protocol Based on Link Correlation for Urban VANETs," IEEE Trans. Mob. Comput., vol. 15, no. 7, pp. 1586-1599, Jul. 2016.

[25] X. M. Zhang, K. H. Chen, X. L. Cao, and D. K. Sung, "A Street-Centric Routing Protocol Based on Microtopology in Vehicular Ad Hoc Networks," IEEE Trans. Veh. Technol., vol. 65, no. 7, pp. 5680-5694, Jul. 2016. 